\title{
The Geopolitics of COVID-19: A Pragma-Cognitive Approach
}

\author{
Rania Magdi Fawzy \\ Arab Academy for Science, Technology \& Maritime Transport \\ raniamagdi33@hotmail.com
}

\begin{abstract}
This study intends to investigate the outbreak of coronavirus, scientifically known as COVID-19, within the context of discursive geopolitics. In so doing, Cap's proximization is particularly suitable to address the cognitive paradigm of critical geopolitics. Cap's proximization, as a pragma-cognitive framing device based on tempo-spatial dimensions, conceptualises the geopolitical identity of coronavirus by associating it with the qualities of space and time. It is found that the NYT reporting of the corona event is framed in certain tempo-spatial configurations which cognitively endorse and proximize the geopolitical identity of the Chinese threat. The notion of metaphorical scenario (Kövecses, 2003; Musolff, 2004), originated in the Conceptual Metaphor Theory (Lakoff, 1993; Lakoff \& Johnson, 1980/2003) is then deployed to show how a geopolitical scenario of a CHINESE THREAT is represented in the NYT. China is being laid before us spatially and temporally as the culprit behind the outbreak of coronavirus. The study aims to give guidance to the field of discursive geopolitics by suggesting cognitive pragmatics as suitable tool for analyzing the construction of geopolitical entities.
\end{abstract}

Keywords: COVID-19; disease geopolitics; Chinese threat; Proximization Theory; tempo-spatial identity

\section{Introduction}

In late 2019, (COVID-19), a new strain of coronavirus emerged in Wuhan, China. Being responsible for infecting hundreds of thousands people worldwide, the virus occurred initially in China and then spread to the rest of the world. Typical symptoms of the virus include fever, fatigue and cough. The first cases of coronavirus were linked to seafood market in Wuhan. Coronavirus transmits Journal of Scientific Research in Arts Language \& Literature 
from one person to another through respiratory droplets (WHO, 2019). As of March 2020, COVID-19 was declared by World Health Organization (WHO) as a global pandemic.

The current paper focuses primarily on the geopolitical cognitive discourse of threat. Exploring the geopolitics of coronavirus from the cognitive motifs of time and space allows understanding the ways in which the identity of the Chinese threat is formed. When tailoring political identities, the complex interactions between time and space configurations which "are non-random and compelling as "contexts"' (Blommaert \& De Fina, 2017, p.1) assume a significant role. According to Blommaert \& De Fina (2017, p.3), every socially shared value ascribed to specific forms of identity is instantiated in particular timespace frames. Specific tempo-spatial dimensions allow the conceptualization of particular modes of behaviour as positive or negative through deploying relevant 'indexicals'. Such indexicals negotiate certain identities and values when deployed within a particular timespace configuration. To put it differently, tempo-spatial identity construction connects "specific timespace arrangements with ideological and moral orders, projecting possible and preferred identities" (Blommaert, 2017, pp. 95).

The geopolitics of disease can be interpreted within larger political and institutional context of power relations. Within the realm of critical geopolitics, the fear of disease serves as a "vehicle for the consolidation of hegemonic interests in the guise of global health security" (Ingram, 2011, p. 660). Examining the notion of global health through the lens of geopolitics is significant in revealing how "geographical space is represented as signified occurring, managing and aggrandizing power" (Bassin, 2004, p. 620 as cited in Ingram, 2005, p. 525). For Ingram (2009, p. 2084), when a disease is construed as global, it is interpreted as geopolitical as well. This is evident in the discourse reporting the emerging of infectious diseases such as HIV/AIDS, tuberculosis, severe acute respiratory syndrome (SARS) and avian influenza. However, the notions of the discourse of disease geopolitics and geopolitical health are underresearch area (Ingram, 2005, p.523). That being said, the aim of this article is to situate the outbreak of coronavirus within the larger context of the geopolitical discourse of the Chinese threat.

Almost there is a near-global consensus on the seriousness of the threat posed by the outbreak of coronavirus. Disturbing the domestic affairs of China while continuing to drastically impact global travel and tourism, world economy, Journal of Scientific Research in Arts l.ansuage \& l.iterature 
coronavirus is validated as a geopolitical event as much as a public health concern. In this article, the outbreak of coronavirus is conceptualized as a 'geopolitical event', an event which is considered "a disruptive transformation of the world and of ways of sensing and making sense of it" (Ingram, 2019, p. 17). In this regard, the theoretical framework under discussion represents coronavirus as an issue in the realm of political rather than medical discourse. The pragma-cognitive approach of this paper relates the conceptualization of A CHINESE THREAT to the spatial and temporal representations of coronavirus in the New York Times (NYT) articles. More specifically, the study seeks to explore how the geopolitics of coronavirus outbreak is influenced by the larger geopolitical debate on the political threat posed by China.

\section{Research Questions}

The current study aims to continue the discursive geopolitical debate on disease by relating the emergence of coronavirus to the geopolitics of the Chinese threat.

The aim of the study is thus framed by the following overarching question and its following sub-questions:

1. How is the geopolitical discourse of the Chinese threat represented within the NYT coverage of coronavirus?

a. What are the tempo-spatial motifs conceptualizing coronavirus?

b. How do the cognitive motifs of time and space frame the identity of the Chinese threat?

c. What are the resulted metaphorical scenarios of these tempo- spatial frames?

\section{The Discursive Geopolitics of Disease and Threat}

Generally speaking, geopolitics is defined according to the ways in which political relationships are shaped by economic and demographic factors linked to geography. Dalby (1990, 1991), O'Tuathail (1989) and O'Tuathail and Agnew (1992) extend the concept of discourse into the field of geopolitics. O'Tuathail and Agnew (1992, p.190) define geopolitics as a discursive practice through which 'intellectuals of statecraft 'spatialize' international politics and represent it as a 'world' characterized by particular types of places, peoples and dramas." Commenting on the notion of discursive geopolitics, O'Tuathail and Agnew (1992, p.191) argue that it is only through discourse that taking a decision of invasion is legitimized. "It is through discourse that leaders act, through the mobilization of certain simple geographical understandings that foreign-policy actions are explained and through ready-made geographicallyJournal of Scientific Research in Arts l.anguage \& Literature 
infused reasoning that wars are rendered meaningful." Conceived as a discursive medium, geopolitics has the ability to produce and circulate spatial representations of global politics (Dodds, 2007, p. 40). Geopolitics discursively arranges different political actors 'spatially' on a global 'chessboard' (O'Tuathail, 2003, p. 1). The discursive power of geopolitics is utilized in conceptualizing the identities of specific countries. Under the tenet of geopolitics, certain spaces are perceived as being of strategic importance while others are conceptualized as marginal. Some spaces are seen as posing threats while others provide opportunities.

Ingram (2005) studies the consequences of diseases within the tents of geopolitics to reflect on the subsequent construction of countries identities. He (2009, p. 2085) argues that disease can be perceived as a geopolitical notion relying on two assumptions: first, disease is governed by a world that is unequal; second, reactions to disease spatially enframe countries and geographical places. For Ingram (2007, p. 522), disease corresponds to the notion of geopolitics in terms of four main perspectives: destabilization, sovereignty, the instrumentalization of health, and geopolitical economy. Governing disease is geopolitical in terms of drawing segregating borders between people, places and countries as a manner of a socio-spatial management of contagion (Bashford, 2006, p. 1 as cited in Ingram, 2009). Informed by this, the current study aims to continue this geopolitical debate on disease by relating the emergence of coronavirus to the geopolitics of the Chinese threat.

Within the discourse of threat, places are questioned in terms of whether or not "they fit into global schemas of security interests and commitment and how these in turn reflect "national interests and identities"” (Agnew, 2010, p. 570). The concept of the 'China threat' and China as a 'regional imperial aggressor' is not new; its history in the West is more than a century ago (Rolf and Agnew, 2016, p. 260). Conceptualizing China as either threat or hope are the two main perspectives that occupy the Western discourse since the $19^{\text {th }}$ century (Agnew, 2010, p. 572). According to Agnew (2010, p. 572), foreign commentators often enframe China's geopolitical position in terms of anxiety and dread. He provides examples with Red Dragon Rising: Communist China's Military Threat to America (Timperlake and Triplett, 1999); China: the Gathering Threat (Menges, 2005); Hegemon: China's Plan to Dominate Asia and the World (Mosher, 2000), and The Beijing Consensus: How China's Authoritarian Journal of Scientific Research in Arts Lansuage \& Literature 
Model Will Dominate the Twenty First Century (Halper, 2010). Accordingly, the geopolitical argument on the 'China threat' is a discursive American construction of a geopolitically imagined Other. Through the discourse of the Chinese threat, America constructs itself as an indispensable state in constant need of security (Pan, 2004). The American geopolitics of the Chinese threat conceptualizes a rising China as an increasing and imminent threat to its neighbours and to far-distant countries. In this regard, the current study examines how the reporting of coronavirus corresponds at large to this American prevailing vernacular.

\section{Methods and Theory}

\subsection{Data Selection}

As an American newspaper of a liberal political orientation (Trckova, 2015), the study analyses NYT hard news on coronavirus to examine the geopolitical representation of the virus. The data consist of 20 hard news articles published in 2020, covering the time span from the outbreak of the virus to announcing it as pandemic in 11/3/2020. The study limits itself to this time span since announcing the virus as pandemic by WHO, marks a shift of focus from China to the rest of the world where the virus spreads. The data are retrieved from the online archive of NYT by entering the keywords 'coronavirus' and 'COVID19 '.

\subsection{Research Procedures}

The current study aims at a synergy between geopolitics and other fields of linguistics, namely cognitive pragmatics. Proximization theory is suitable here since it aims at analysing the discursive conceptualizations of two entities, whereas one of these identities is framed as the imminent threat. From a geopolitical perspective, proximization fits for the analysis of the discursive representations of the hegemonic Other as posing threats. It provides the lexicogrammatical tools to study the discursive conceptualization of 'movement' of the Other as the central deictic threat (Cap, 2017, p. 16). Decoding the tempospatial motifs of proximization marks the first step of the analysis. The study, then, deploys the tools of Proximization to unveil metaphor scenarios (Kövecses, 2003; Musolff, 2004) as means for representing geopolitical ideologies, namely the geopolitics of the Chinese threat. The notion of metaphorical scenario (Kövecses, 2003; Musolff, 2004), originated in the Conceptual Metaphor Theory (Lakoff, 1993; Lakoff \& Johnson, 1980) is then Journal of Scientific Research in Arts l.anguage \& Literature 
utilised to show how a geopolitical scenario of a Chinese threat is represented in the NYT.

The articles are analysed manually by the author. Firstly, deictic expressions of space and time are searched for. Then these expressions are examined through a cognitive lens as motifs of geopolitical identities. After that, the underlying metaphorical themes are mapped accordingly. Typographic attributes are used to in-text encode the tempo-spatial indexicals as follows:

Bold $=$ spatial

$\underline{\text { Underlined }}=$ temporal

$\underline{\text { Bold underlined }}=$ Tempo-spatial

\subsection{Proximization Theory}

Proximization Theory is a relatively recent approach that extends the work of 'Deictic Discourse Space' proposed by Chilton (2004). It marks a pragmacognitive analysis of crisis and threat construction (Cap 2006, 2008, 2010, 2013). Proximization, meaning bringing 'conceptually closer', is a discursive strategy that is deployed to examine the discourse of conceptualizing tempospatial distant events as negatively getting closer to the speaker and the putative reader. In this regard, the speaker intends to negotiate negative instantiations of 'foreign', 'alien', and 'antagonistic' deictic entities. This, in turn, would 'legitimize' and neutralize actions and policies proposed by the speaker (Cap, 2013, p. 293).

Proximization theory examines the cognitive representation of identities within the Discourse Space (DS). See figure 1. 


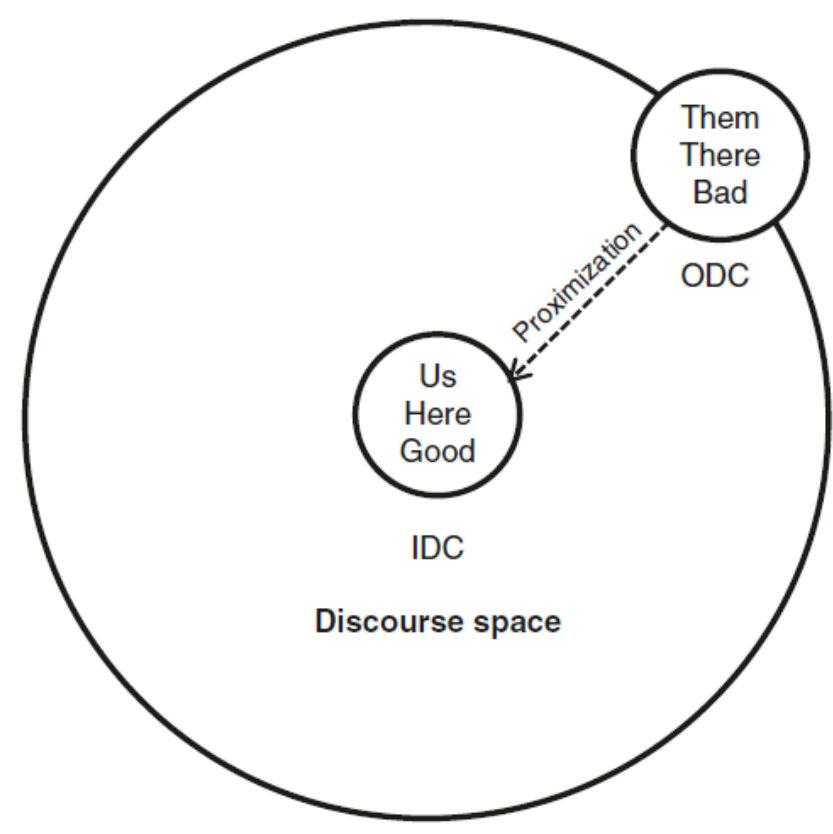

Figure 1 Proximization in Discourse Space DS, Cap 2017

Figure 1 presents a symbolic strategic operation which conceptualizes external entities as approaching the centre of DS in the service of social and political agendas (Cap, 2013, p. 47). The threat is posed from the DS external entities, 'Outside Deictic Centre' (ODC). These entities are negatively conceptualized as invading the space of the 'Inside Deictic Centre' (IDC) entities. The conceptualized threat is thus of a spatio-temporal nature.

Ideological proximization is conceptualized through three aspects: 'spatial proximization', 'temporal proximization' and 'axiological proximization'. Spatial proximization represents the physical encroachment of the DS external entities upon the DS central entities (speaker, addressee). As for temporal proximization, it conceptualizes the projected conflict as imminent, momentous and historic, necessitating immediate preventive measures. Temporal proximization typically deploys analogies to closely associate the conceptualized current threat with other occurrences in the past, endorsing the current negative scenario. According to Cap (2013), temporal proximization is a symbolic 'compression' of the time axis which conflates time frames, instantiating two simultaneous conceptual shifts (p.85-86): past-to-present shift and future-to-present shift. The past-to-present instantiations analogically validate the past events and actions performed by the ODC entities as informing the addressee's present threatening context. As for the future-to-present shift, it constructs the near future ODC actions as stemming directly from the present 
context, necessitating immediate action. Finally, 'axiological proximization' is "a construal of a gathering ideological clash between the "home values" of the DS central entities (IDCs) and the alien and antagonistic (ODC) values" (Cap, 2013, p. 295).

Table 1 Lexico-grammatical references of spatial proximization (Cap 2017, p. 19)

\begin{tabular}{|c|c|}
\hline Category & Key items \\
\hline $\begin{array}{l}\text { 1. Noun phrases (NPs) construed } \\
\text { as elements of the deictic centre } \\
\text { of the DS (IDCs)) }\end{array}$ & $\begin{array}{l}\text { ['USA', 'United States', 'America']; } \\
\text { ['American people', 'Americans', 'our } \\
\text { people/nation/country/society']; ['free } \\
\text { people/nations/countries/societies/ } \\
\text { world']; ['democratic people/nations/ } \\
\text { countries/societies/world'] }\end{array}$ \\
\hline $\begin{array}{l}\text { 2. (NPs construed as elements outside } \\
\text { the deictic centre of the DS (ODCs)) }\end{array}$ & $\begin{array}{l}\text { ['Iraq', 'Saddam Hussein', 'Saddam', } \\
\text { 'Hussein']; ['Iraqi regime/dictatorship']; } \\
\text { ['terrorists']; ['terrorist organizations/ } \\
\text { networks', 'Al-Qaeda']; ['extremists/ } \\
\text { radicals']; ['foreign regimes/dictatorships'] }\end{array}$ \\
\hline $\begin{array}{l}\text { 3. (Verb phrases (VPs) of motion and } \\
\text { directionality construed as markers } \\
\text { of movement of ODCs towards the } \\
\text { deictic centre) }\end{array}$ & $\begin{array}{l}\text { ['are determined/intend to seek/acquire } \\
\text { WMD']; ['might/may/could/can use } \\
\text { WMD against an IDC] ] ['expand/grow in } \\
\text { military capacity that could be directed } \\
\text { against an IDC']; ['move/are moving/ } \\
\text { head/are heading/have set their course } \\
\text { towards confrontation with an IDC'] }\end{array}$ \\
\hline $\begin{array}{l}\text { 4. (VPs of action construed as markers } \\
\text { of impact of ODCs upon IDCs) }\end{array}$ & $\begin{array}{l}\text { ['destroy an IDC ]; ['set aflame/burn down } \\
\text { an IDC or IDC values'] }\end{array}$ \\
\hline $\begin{array}{l}\text { 5. NPs denoting abstract concepts } \\
\text { construed as anticipations of impact } \\
\text { of ODCs upon IDCs) }\end{array}$ & ['threat']; ['danger'] \\
\hline $\begin{array}{l}\text { 6. NPs denoting abstract concepts } \\
\text { construed as effects of impact of ODCs } \\
\text { upon IDCs) }\end{array}$ & ['catastrophe']; ['tragedy'] \\
\hline
\end{tabular}

The six linguistic categories displayed by the left column are the elements constituting the spatial proximization framework. As for the illustrations of the right column, it varies according to the discourse under analysis. Cap here includes the most deployed spatial deictic references in the 2001-2010 presidential speeches on the US anti-terrorist discourse.

As for the temporal proximization framework, it includes the following five categories as summarized by Neuff (2018, pp. 12-13):

1. NPS describing ODC impact within temporal frames

2. Contrastive utilization of past and present tenses, highlighting constant future threat that is related to and expanding past state of affairs. Journal of Scientific Research in Arts l.anguage \& Literature 
3. NPs of nominalised presupposition of ODC negative impact to be anticipated in the future.

4. VPs in the form of modal auxiliaries representing the ODC impact as constantly relating 'the now' with and the infinite future.

5. Discursive construal of contrastive and advantaged futures emerging from the now.

Thirdly, the three markers of axiological proximization are:

1. NPs conceptualizing the positive values of IDC.

2. NPs construing ODC negative values.

\subsection{Metaphorical Scenarios}

Mapping of individual instances of conceptual metaphors is undertaken to identify the basis upon which particular metaphor scenarios can be instantiated (Marissa, 2020; Musolff, 2016, 2004). Marissa (2020, p. 5) notes that metaphor scenarios help in framing the story-lines that is instantiated through the mappings between source and target domains of the deployed metaphors.

The notion of 'metaphor scenario' is defined as 'ensembles of little scenes or story-lines", these little scenarios are derived from a collection of "standard assumptions made by competent members of a discourse community about the 'prototypical' content aspects (participants, roles, 'dramatic' story-lines) and social/ethical evaluations concerning elements of conceptual domains" (Musolff, 2004, p. 17).

In the current paper, the mapped metaphor scenarios that frame the geopolitical conceptualization of the Chinese threat are realized through the tempo-spatial configurations of the proximization strategies. According to Kövecses (2017), metaphor scenarios function at the level of mental spaces, facilitating understanding and action (Marissa, 2020).

\section{Analysis}

The pragmatic proximization strategies adopted in NYT articles on coronavirus act as tempo-spatial indexicals, which in turn, instantiate geopolitical identities. The construed identity tells the readers less about the virus, how to deal with it, its humanitarian impact...etc. and more about the identity of a threatening China. The individual conceptual metaphors that make up the metaphorical scenario of coronavirus as a manifestation of a geopolitical Chinese threat are illustrated in Table 2.

Table 2. List of metaphorical repertoires under the geopolitical discourse of a threatening China.

\begin{tabular}{l|c}
\hline Theme & Discourse \\
\hline
\end{tabular}

Journal of Scientific Research in Arts Lansuage \& literature 
THE CHINESE POLITICAL

THREAT

The geopolitics of a threatening

THE CHINESE DEMOCRATIC

THREAT

THE CHINESE ECONOMIC

THREAT

\section{Geopolitics of CHINESE POLITICAL THREAT}

China is conceptualized as a political geopolitical threat by imbuing it with the geopolitical discourse of a VILLAIN STATE. Proximization strategies are used to delineate a threatening Chinese identity, foreign to that of the Western society in general, and the United Stated in particular. This, in turn, achieves the dichotomous cognitive conceptualization of an in-group versus an out-group (van Dijk, 1998) or in other words, deictically-central and deictically-peripheral geopolitical identities.

The tempo-spatial markers deployed in the NYT articles create a Chinese identity with which the deadly spread of coronavirus is associated.

- For China's leader, Xi Jinping, the outbreak is not just a health crisis, but a political one.

- Xi stays out of the spotlight, but he might not escape blame.

- The coronavirus outbreak spreading from China.

- There have been only two confirmed deaths from the new coronavirus outside mainland China: one in Hong Kong and one in the Philippines.

- Wuhan, the epicenter of the outbreak, is also home to one of the most advanced epidemic disease research laboratories in the world.

- Many doctors believe that deaths and infections from the current epidemic are undercounted in China because testing facilities are under severe strain.

The first example deploys tempo-spatial motifs which conflate the geopolitics of health and political crises. The second example even casts the blame explicitly on the Chinese president $\mathrm{Xi}$. The temporal adjective 'current', the temporal deictic adverb 'now' and the repeated use of the spatial gerund 'spreading' all serve to explicitly proximiz the Chinese threat. The two deictic prepositions 'from' and 'outside' found in the second and third examples respectively present a transitional space between two worlds: the Chinese world and the rest of the globe. This notion is further supported with the spatial lexical Journal of Scientific Research in Arts language \& literature 
motifs 'mainland', 'epicenter' and 'home', depicting China as the source of the virus. The CONTAINER metaphor is evident (Lakoff and Johnson, 1980/2003), CHINA AS CONTAINER OF THE VIRUSE. The spatial deictic 'under' in the sixth example is of special interest. It encodes the spatial location of the outbreak of the 'current epidemic' as relative to the location of the spatial psrticipants (China and testing facilities). Instantiating Lakoff and Johnson's (1980, p. 15 ) UP / DOWN orientational metaphor, deictic 'under' negotiates CHINESE LACK OF CONTROL metaphor, conceptualizing the failure of the Chinese governing system in controling the spread of coronavirus.

The evolution and the consequential impact of the CHINESE POLITICAL THREAT geopolitics are indexed as well in the text through the use of NPs which represent the IDCs centre. Consider the following examples:

- An American in Wuhan has died from the coronavirus.

- Coronavirus Cases in the United States Reach 34, and More Are Expected

- More cases are reported in Britain and Spain.

- A majority of the cases have been in Washington State, California or New York, where everyday life swiftly began to change. Businesses closed. Colleges canceled class. Governors urged people to avoid crowds.

- France will shut two schools while investigating a cluster of new cases.

- The count: 28 countries, with a spike in South Korea

- U.S. Cases of Coronavirus Surpass 1,000; British Health Minister Is Infected

- From eastern Asia, Europe, the Middle East, the Americas and Africa, a steady stream of new cases on Friday fueled fears that the new coronavirus epidemic may be turning into a global pandemic, with some health officials saying it may be inevitable.

The Chinese threat is presented in these examples as extending from China and its own people to 'our own people' and finally to the broader 'world'. Thus, along with a 'disease-knows-no-borders' rhetoric motif, the lexical markers of the Western IDC entities, such as 'America', 'Britain', 'France', 'Spain' and 'Korea' are motifs of in-groupness. The declarative mood of these statements relates to the commissive illocutionary force of a future threat, creating future to present temporal axis. The illocutionary forces of anticipated threat emphasize that future threats posed against the Western society is determined by the present Chinese practices concerning the handling of coronavirus. The adverb 'more', the temporal deictic 'will' and the temporal adjective 'new' carry tempo-spatial properties, construing future to present shift. Another proximization strategy which is apparent in the previous examples is the use of

Journal of Scientific Research in Arts Language \& Literature 
lexical quantifiers 'more' and 'majority'. Although being non-spatial entities, numbers such as $(34,28,1000)$ can be metaphorically understood in spatial terms (Borneto, 1996, p. 383).These scalar quantifiers are also considered of temporal nature not spatial alone since they refer to and emphasize the occurrences of the virus at 'different times'.

It is worth noting that no Eastern infected country is mentioned in the NYT headlines of the entire corpus except for Iran which is represented negatively. The following example is illustrative:

- 'Recipe for a massive viral outbreak': Iran emerges as a worldwide threat

- Long a regional crossroads, Iran is spreading the new coronavirus to a host of neighboring countries.

The deployed tempo-spatial motifs construe Iran within the same axiological axis of China.

The geopolitics of the Chinese threat is framed discursively in the articles under discussion through deterritorialized and atemporal deictic expressions. Consider the repeated use of the quantified bare-NP adverb of location 'every' and spatial deictic 'here' in the following examples:

- Every county, every village around here is now putting up barriers, worried about that disease.

- The fast spread of $\mathrm{CoV}-2019$ - more than 4,500 confirmed cases, including at least 106 deaths, as of Tuesday morning, and the figures will have risen by the time you read this is startling but not unforeseeable.

- In other words, this Wuhan emergency is no novel event. It's part of a sequence of related contingencies that stretches back into the past and will stretch forward into the future, as long as current circumstances persist.

The distributive quantifier 'every', and demonstrative pronouns 'here' and 'this' carry both spatial and temporal properties. 'Every' invokes a notion of succession, converting the temporal situation into an atemporal and deterritorialized one. As for the demonstratives 'here' and 'this', they proximize the addressee at the center of the deictic field of threat. The significant use of the future perfect in the second example 'will have risen' indicates that the reporter adopts a viewpoint in the deictic future as a result of the current Journal of Scientific Research in Arts l.anguage \& Literature 
situation (Radden \& Dirven, 2007). In this particular example, the present perfect denotes the fast stretching of the virus outbreak time up to a very near point in time 'by time you read this' as a result of the current Chinese policies. The last example describes the Chinese threatening situation as infinite. This notion is achieved through the use of the temporal VPs of action 'stretches back', 'stretch forward' and the dialectical clash between the spatial deictic 'this' and the temporal references 'will' as well as between the lexical items 'past' and 'future'. The geopolitics of the Chinese threat is thus conceptualized as INFINITE AND LASTING THREAT.

Table 3 Metaphorical scenario for the Chinese political threat

\begin{tabular}{lccc}
\hline $\begin{array}{l}\text { Source Domain Conceptual } \\
\text { Metaphors }\end{array}$ & $\begin{array}{c}\text { Theme } \\
\text { Metaphor }\end{array}$ & realised by \\
\hline CHINA AS VILLAIN STATE & China is a political \\
CHINA AS CONTAINER OF & threat & &
\end{tabular}

THE VIRUSE

CHINESE LACK OF

CONTROL

INFINITE AND LASTING

THREAT

\section{Metaphorical Scenario}

China and its failed system pose constant political threat to the Western society exemplified in the spread of coronavirus.

\section{Geopolitics of CHINESE DEMOCRATIC THREAT}

Within a geopolitical framework, the spread of epidemic coronavirus is conceptualized as having a negative impact on global democracies. The tempospatial proximization strategies adopted in NYT linke the Chinese repressive government system and circumscribing polices with the deadly outbreak of the virus. The virus threat is thus depicted as representative of the CHINESE REPRESSIVE SYSTEM. 
- China Silences Critics Over Deadly Virus Outbreak.

- Chinese Doctor, Silenced After Warning of Outbreak, Dies From Coronavirus

- WUHAN, China - More than 700 people have died. Tens of thousands are infected. Millions are living under lockdown, and the government has sought to silence complaints.

- In the middle of the night, officials from the health authority in the central city of Wuhan summoned $\mathrm{Dr}$. Li, demanding to know why he had shared the information. Three days later, the police compelled him to sign a statement that his warning constituted "illegal behavior."

- A lawyer who had provided a rare glimpse into the dire conditions in Wuhan, the epicenter of the coronavirus outbreak, has gone missing, his friends say, expressing fear for his safety.

The spatial lexico-grammatical VPs of actions such as 'silence critics', 'summoned', 'compelled him to ...,' 'has sought to silence complaints,' and 'has gone missing' conceptualize REPRESSIVE CHINA (the ODC). China is conceptualized as a tightly circumscribed space. The deployed VPs of silencing actions stand as spatial indexicals of the contrast between the authoritative Chinese practices of freedom supression and the Western democratic 'teachings'. The NPs of 'China', 'Chinese government' and 'officials from the health authority in the central city of Wuhan', are spatial markers established as entities outside the frame of the DS. The IDCs in these examples are the democratic values of the Western society. These examples manifest a dialectical tension between the 'home values' of the DS central entities, being the democratic Western society and the Chinese repressive values. China, the geographically distanced actor is 'now' conceptualized as encroaching towards the in-group members in the form of a virus. Proximizing the Chinese threat, the axiological distance of China and the Western world grows as negative image of China is construed.

Temporal proximization intensifies the spatial proximization (Hart, 2014). The CHINESE DEMOCRATIC THREAT conceptualized in the articles under Journal of Scientific Research in Arts l.anguage \& l.iterature 
discussion is manifested through temporal proximization as well. Temporal abstract concepts carried by the NPs are deployed as markers of the repressive impact of ODCs upon IDCs. Consider the temporal markers 'martyr' and 'death' in the following examples:

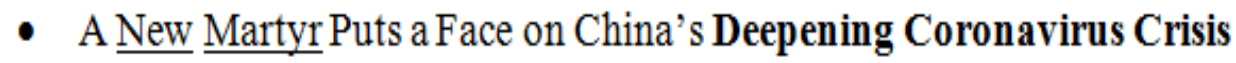

- The deluge of mourning and anger at the death of the doctor, Li Wenliang

The two abstract nouns 'death' and 'martyr' act as 'ontological metaphors', marking a shift from a relational entity into a thing (Radden \& Dirven, 2007, p. 78). The nouns 'death' and 'martyr' are linked to temporality here since they represent episodic states which are bounded by time. They are set as a reference to the specific time in which China exercises its circumscribing policies. The event of the death is then viewed from a temporal vantage point which stands as a representation of the Chinese policy in handling coronavirus. As such, deploying ontological metaphors here allows us to understand Chinese policies in terms of death and martyrdom. The temporal references are further upscaled and intensified by the spatial NPs: 'deepening', 'crisis' and 'deluge'.

Significantly, the doctor Li Wenliang's story is foregrounded as indexical motif of the Chinese democratic ill practices. Dr Li becomes a representative icon for the IDC and the rest of the world who are losing their lives from the virus due to the Chinese repressive and blacking out policies.

- When $\mathrm{Dr}$. Li, 34, warned of the virus in an online chat room more than five weeks ago, the police made him an example of what befalls those who do not comply with official demands for secrecy. He was summoned by the authorities and forced to sign a statement denouncing his warning as an unfounded and illegal rumor.

- Chinese academics, professionals and others have created digital petitions calling for freedom of speech amid a widespread outpouring of anger and grief online for $\mathrm{Dr}$. $\mathrm{Li}$ Wenliang, who gave early warnings about the coronavirus in Wuhan, only to die of it last week himself.

The sentimental appeal of Dr. Li Wenliang story relates itself to affectual discourse. The discourse of affective bonding between infected families is deployed as well, emphasizing the negative consequences of the Chinese Journal of Scientific Research in Arts l.anguage \& Literature 
blackout policies. The authoritative and oppressive governing system of China is represented as negatively impacting families. China's blacking out the reality of coronavirus renders it affecting the whole Chinese community in their everyday life and extends to affect the whole world. The following examples are illustrative:

- Her Grandmother Got the Coronavirus. Then So Did the Whole Family.

- When Dong Guanghe developed a fever on Jan. 8 in Wuhan, his family was not alarmed, his daughter said. He was treated in the hospital and sent home. Then, 10 days later, Mr. Dong's wife fell ill with similar symptoms. "The news said nothing about the severity of the epidemic," said the daughter, Dong Mingjing. "I thought that my dad had a common cold."

The spatial NPs indexicals: 'her grandmother', 'the whole family', 'his family' and 'Mr. Dong's wife' all act as spatial markers which emphasis the spread of the virus to all the family members.

Another discursive strategy used by the NYT to achieve atemporal proximization effect is the use of past analogy. SARS event is proximized via erasing the boundaries between the abstract times so that it is conceptualized as being conflated with the present situation. In the following examples, spatial and temporal proximizations deploy fear appeals through the use of SARS analogy, conflating the growing coronavirus threat with past emergence of other deadly virus.

- The coronavirus death toll in China has risen to 908, surpassing the toll from the SARS epidemic of 2002-3, according to official data.

- Deaths in China from Coronavirus Reach 811, Surpassing SARS Toll

- The SARS disaster was supposed to drag China into a new era of openness and responsibility. The deadly disease rippled across the world 17 years ago, abetted by a

Chinese government that covered up its spread. As the scope of it became clear, China's journalists, intellectuals and other critics helped shame Beijing into opening up about the problem.

Diverging itself from the natural cycle of the abstract time, the conceptualization of a current geopolitical Chinese threat is represented as stemming from a past repressive politics. The analogy here is not a simple recalling of a past handling of similar virus outbreak. The examples reinforce Journal of Scientific Research in Arts l.anguage \& Literature 
the repressive policies of covering up and hiding information. The use of the present perfect tense in the first example emphasizes that coronavirus is even much dangerous and threatening. This idea is further stressed by the repeated NPs of participial gerund 'surpassing'. The tempo-spatial tension between the VPs 'was supposed', 'abated' and 'covered up' and the NPs 'new era' and 'opening up' maps the source metaphor of CHINESE RECURSIVE GOVERNING SYSTEM. SARS analogy is employed by the speaker in order to bring Chinese recursive policies, which apply the same circumscribing procedures repeatedly, conceptually closer.

The analogy enacts a temporal analogy 'axis' (Cap, 2013), associating the 'past' outbreak of SARS with the present spread of coronavirus, constructing a deictic analogy between the proximized historical acts of dictatorship and the current mishandling of the the coronavirus spread.The NYT, thus, establishes the past, 'the now' and the near future as the indexical timeframes. The following example restates the same notion.

\section{As $\underline{\text { New }}$ Coronavirus Spread, China's Old Habits Delayed Fight.}

The dialectical tension established between the temporal NPs 'new' and 'old' and the tempo-spatial VPs 'spread' and 'delayed' emphasizes further Chinese recursive practices. The CHINESE THREAT is then established as continual and inevitably extending to the future. The The NYT articles present a sense of past-present / future-present connection and orientation, emphasizing linear temporality. The Chinese situation seems poised between ill-practiced past, a turbulent present and uncertain future. Although past and future are normally oriented in two opposing directions, the analogy in these examples brings them conceptually in one point, empasizing China's recurssive polices. The Chinese political practices are conceptualized as proximal rather than distal in the past/present/future axis.

Table 4 Metaphorical scenario for the Chinese democratic threat Source Domain Conceptual Metaphors Theme realised by Metaphors

CHINESE REPRESSIVE SYSTEM

INFINITE AND LASTING THREAT

China is a

CHINESE RECURSIVE GOVERNING threat SYSTEM

\section{Metaphorical Scenario}

The mapped source metaphors instantiate a

Journal of Scientific Research in Arts lansuage \& l.iterature 
dialectical tension between the authoritative Chinese practices of freedom supression and the Western democratic values. Deterritorialized and atemporal metaphorical mappings constructs set the scenario of a Chinese democratic threat that is imminent, urging an immediate action to be taken.

The NYT frames China as a geopolitical enemy by using metaphors from the source domain of democratic threat. The metaphorical scenario of CHINESE DEMOCRATIC THREAT Corresponds to Chilton's views on the political rhetoric of delegitimisation which can manifests itself in the act of "... attacking the moral character of some individual or group" (2004, p. 47, author's italics).

\section{Geopolitics of CHINESE ECONOMIC THREAT}

Spatio-temporal proximization strategies are deployed in the articles under discussion to conceptualize the geopolitics of economic threats.

- As the coronavirus outbreak rattles the global economy and disrupts supply chains, international companies across nearly every industry are confronting a stark reality: Business will not go on as usual.

- Car factories are idling in China, raising global concerns.

- Chinese car and auto parts factories may stay closed longer than expected because of the Coronavirus.

- Coronavirus stymies global trade and global businesses.

- The International Air Transport Association this week warned of a deep downturn in earnings among global carriers related to the collapse of travel in Asia because of the virus.

Temporal proximization is realised in the present progressive form of the VPs 'are confronting' and 'are idling', stressing the continual and constant negative effect of the virus. This idea is further reinforced by the AP 'raising', indicating the rapidly growing rate at which the outbreak continues to happen. The threat is conceptualized as extending to the 'world' by the repeated use of the 
nominalised predicate 'global'. The prepositional phrase 'in China' spatially assigns the role of the culprit to China.

The role of the culprit is ascribed also to the Chinese government and the Chinese people due to their 'weird' eating habits, assigning a STIGMATIZED GEOPOLITICS OF DISEASE metaphor. Conceptualizing the geopolitics of CHINESE ECONOMIC THREAT, eating traditions and economic practices are motifs themselves that make the cognitive mapping of the threat more identifiable.

- Current circumstances include a perilous trade in wildlife for food, with supply chains stretching through Asia, Africa and to a lesser extent, the United States and elsewhere. That trade has now been outlawed in China, on a temporary basis; but it was outlawed also during SARS, then allowed to resume - with bats, civets, porcupines, turtles, bamboo rats, many kinds of birds and other animals piled together in markets such as the one in Wuhan.

- It may have started with a bat in a cave, but human activity set it loose.

The geopolitical spatial distance is cognitively conceptualized as getting smaller towards the IDC (the rest of the Western society).

\begin{tabular}{|c|c|}
\hline Source Domain Conceptual Metaphors & $\begin{array}{l}\text { Theme } \\
\text { realised by } \\
\text { Metaphors }\end{array}$ \\
\hline CHINA IS A CULPRIT & China is \\
\hline $\begin{array}{l}\text { STIGMATIZED } \\
\text { DISEASE }\end{array}$ & $\begin{array}{l}\text { economic } \\
\text { threat }\end{array}$ \\
\hline $\begin{array}{l}\text { Metaphorical Scenario } \\
\text { Chinese eating practices and their wildlife } \\
\text { markets impact negatively the global } \\
\text { economy. }\end{array}$ & \\
\hline
\end{tabular}

Commenting on the construction of threatening geopolitical identity, Cap (2017) argues that the discourse of threat functions within the realm of geopolitics through the paradigms of fear and failure to manage the crisis situation (Cap, 2017, p. 9). The metaphorical scenario of the Chinese economic threat is conceptualized through the geopolitics of fearing the economic 
consequences of coronavirus. Blaming China for allowing the trade of wildlife animals as food products in its market closely associate it

\section{Conclusion}

This paper has examined how the coverage of coronavirus corresponds to the American prevailing vernacular of the Chinese threat. By analysing the NYT reports on coronavirus, this study contributes to the body of literature on the cognitive analysis of the geopolitics of diseases. The paper has suggested the proximization theory as a useful instrument for examining geopolitical identities through relating them to tempo-spatial materiality of a specific narrative. Cap's proximization, as a pragma-cognitive framing device helps in examining the geopolitical identity of coronavirus by associating it with the qualities of space and time. It reveals the ways certain assumptions about the geopolitics of Coronavirus are communicated within a wider conceptualization of a Chinese threat. It is found that the NYT reporting of the Corona event endorses the geopolitical identity of the CHINESE THREAT. Moreover, Individual metaphors instantiate intensified short scenarios that align with the geopolitical discourse of NYT.

The spatio-temporal manifestations discussed in the current study highlights the discursive conceptualization in which China is presented as the evil 'other'. Spatial deictics are used to proximiz the Chinese threat. A transitional space between two worlds: the Chinese world and the rest of the globe is then established. Spatial motifs underlined in the texts under discussion constitute close connection with the geopolitical notion of the Chinese threat and their reaction the spread of coronavirus.

Temporal proximization of the virus is established through conflating the past, the now and the future time frames, assigning a multi-voiced dialogical motif which constructs the Chinese government as a failure system who does not learn from their past actions. In this temporal frame, present status is not something that is simply happening; rather it results from past, recursive governing system. The threat posed by China to the outside world is then reinforced.

The mapped metaphorical conceptualizations that negotiate the metaphorical scenario of coronavirus as a manifestation of a geopolitical Chinese threat are: THE CHINESE POLITICAL THREAT, THE CHINESE DEMOCRATIC THREAT and THE CHINESE ECONOMIC THREAT. Under the source mapping of THE CHINESE POLITICAL THREAT, for sub-metaphors are negotiated: CHINA AS VILLAIN STATE, CHINA AS CONTAINER OF THE VIRUSE, CHINESE LACK OF CONTROL and INFINITE AND Journal of Scientific Research in Arts l.anguage \& Literature 
LASTING THREAT. Correspondingly, the metaphorical scenario of a Chinese failed system that poses constant political threat to the Western society is, then, delineated. As for the source metaphor The CHINESE DEMOCRATIC THREAT, it is voiced through CHINESE REPRESSIVE SYSTEM, INFINITE AND LASTING THREAT and CHINESE RECURSIVE GOVERNING SYSTEM metaphors. These mapped conceptualizations instantiate a dialectical tension between the authoritative Chinese practices of freedom supression and the Western democratic values. Deterritorialized and atemporal metaphorical mappings constructs set the scenario of a Chinese threat that is imminent, urging an immediate action to be taken. Within the frame of CHINESE ECONOMIC THREAT, the following metaphorical configurations are instantiated: CHINA IS A CULPRIT and STIGMATIZED GEOPOLITICS OF DISEASE, making up a scenario that stigmatizes China for their eating habits and put them responsible for the virus outbreak.

Further studies on the coverage of coronavirus need to be carried out. Later coverage of the virus hardly focuses on China, but rather on Europe, America and now extends also to the rest of the countries, with ample criticism of leaders such as Trump, etc. (even criticising him for calling it the "Chinese virus"). These developments suggest having a broader look at the international coverage. Further studies are needed as well that are not limited to the focus to proximity or spatiotemporal categories. Analysing different genres such as political cartoons and online memes would be of special interest.

\section{References}

Agnew, J. 2010. "Emerging China and Critical Geopolitics: Between World Politics and Chinese Particularity". Eurasian Geography and Economics, 51(5), 569-582.

Bashford, A. (Ed.) 2006. Medicine at the Border: Disease, Globalisation and Security, 1850 to the Present 1-17. Houndmills: Palgrave Macmillan.

Bassin, M. 2004. "The Two Faces of Contemporary Geopolitics". Progress in Human Geography, 28(5) 620-626.

Blommaert, J. 2017. "Mobility, Contexts, and the Chronotope". Language in Society 49(1), 95-99.

Journal of Scientific Research in Arts Language \& Literature 
Blommaert, J. And De Fina, A. 2017. "Chronotopic Identities: on the Timespace Organization of Who We Are". In: De Fina, A. and D., Wenger, J. (Eds.) Diversity and Superdiversity: Sociocultural Linguistic Perspectives, 1-15. Washington: Georgetown University Press.

Borneto, CS. 1996, "Polarity and Metaphor in German". In: Putz, M. And R. Driven. The Construal of Space and Language and Thought, 373-394. Berlin, New York, S.

Cap, P. 2006. Legitimization in Political Discourse: A Cross-Disciplinary Perspective on the Modern US War Rhetoric. Newcastle: Cambridge Scholars Press.

Cap, P. 2008. "Towards the Proximization Model of the Analysis of Legitimization in Political Discourse". Journal of Pragmatics, 40 (1), 1741 .

Cap, P. 2010. "Axiological Aspects of Proximization". Journal of Pragmatics, $42(2), 392-407$

Cap, P. 2013. Proximization: The Pragmatics of Symbolic Distance Crossing. Amsterdam: John Benjamin.

Cap, P. 2014. "Applying Cognitive Pragmatics to Critical Discourse Studies: A Proximization Analysis of Three Public Space Discourses". Journal of Pragmatics, 70, 16-30.

Cap, P. 2015. "Crossing Symbolic Distances in Political Discourse Space: Evaluative Rhetoric within the Framework of Proximization”. Critical Discourse Studies, 12 (3), 313-329.

Cap, P. 2017. The Language of Fear: Communicating Threat in Public Discourse. London and New York: Palgrave Macmillan

Chilton, P, 2004. Analysing political discourse. Theory and Practice. Routledge, London. 
Dalby, S. 1990. "American Security Discourse: The Persistence of Geopolitics.” Political Geography Quarterly, 21(9) 171-188.

Dalby, S. 1991. "Critical Geopolitics: Discourse, Difference and Dissent". Environment and Planning D: Society and Space, (9) 261-283.

Dodds, K. 2007. Geopolitics: A Very Short Introduction. UK: Oxford University Press.

Halper, S., 2010. The Beijing Consensus: How China's Authoritarian Model Will Dominate the Twenty First Century. New York, NY: Basic Books.

Hart, C. 2014. Discourse, Grammar and Ideology: Functional and Cognitive perspectives. London: Bloomsbury.

Kövecses, Z. 2003. The Scope of metaphor. In A. Barcelona (Ed.), Metaphor and metonymy at the crossroads: A cognitive perspective (pp. 79-92). Mouton de Gruyter.

Kövecses, Z. 2017. Levels of metaphor. Cognitive Linguistics, 28(2), 321-347.

Lakoff, G. 1993. The contemporary theory of metaphor. In A. Ortony (Ed.), Metaphor and thought 202-225. Cambridge University Press.

Lakoff, G., Johnson, M., 1980/2003. Metaphors We Live By. Chicago: University of Chicago Press.

Ingram, A. 2005. "The New Geopolitics of Disease: Between Global Health and Global Security”. Geopolitics, 10, 522-45.

Ingram, A. 2007. "HIV/AIDS, Security and the Geopolitics of US-Nigerian Relations". Review of International Political Economy, 14, 510-534.

Ingram, A. 2008. "Pandemic Anxiety and Global Health Security". In: R. Pain and S. J. Smith (eds.) Fear: Critical Geopolitics and Everyday Life. Aldershot, UK: Ashgate.

Ingram, A. 2009. "The Geopolitics of Disease". Geography Compass, 3(6), 2084-2097. 
Ingram, A. 2011. "The Pentagon's HIV/AIDS Programmes: Governmentality, Political Economy, Security". Geopolitics, 16, 655-674.

Ingram, A. 2019. Geopolitics and the Event: Rethinking Britain's Iraq War Through Art, (1 ${ }^{\text {st }}$ ed,.). John Wiley \& Sons Ltd.

Marissa K. L. E (2020): Discourse of future-orientedness as neoliberal ideal: metaphor scenarios as a means of representing neoliberal logics. Critical Discourse Studies, DOI: 10.1080/17405904.2020.1779766

Menges, C. C., 2005. China: The Gathering Threat. Nashville, TN: Nelson.

Mosher, S. W. 2000. Hegemon: China's Plan to Dominate Asia and the World. Lanham, MD: Encounter.

Musolff, A. 2004. Metaphor and political discourse: Analogical reasoning in debates about Europe. Palgrave Macmillan.

Musolff, A. 2016. Political metaphor analysis: Discourse and scenarios. Bloomsbury Academic.

Neuf, M. 2018. Words of Crisis as Words of Power: The Jeremiad in American Presidential Speeches. Amsterdam: John Benjamins.

Ó Tuathail, G. 1989. Critical geopolitics: The Social Construction of Place and Space in the Practice of Statecraft. Unpublished PhD thesis, Syracuse University.

Ó Tuathail, G. 1998. "Thinking Critically about Geopolitics (Introduction)”. In: Ó Tuathail, G., S. Dalby, and P. Routledge (eds), The Geopolitics Reader (London and New York: Routledge

Ó Tuathail, G., 2002. "Theorizing practical geopolitical reasoning: the case of the United States' response to the war in Bosnia". Political Geography, (21): 601-628.

Ó Tuathail, G. and Agnew, J. 1992. "Geopolitics and discourse: Practical geopolitical reasoning in American foreign policy”. Political Geography, 11(2), 190-204. 
Pan, C. X. 2004. "The 'China Threat' in American Self-Imagination: The Discursive Construction of 'Other' as Power Politics". Alternatives 29, 305-331.

Radden, G. and Dirven, R. 2007. Cognitive English Grammar. Amsterdam and Philadelphia, Pa.: John Benjamins.

Rolf, S., Agnew, J. 2016. "Sovereignty Regimes in the South China Sea: Assessing Contemporary Sino-US Relations". Eurasian Geography and Economics 57(2), 249-273.

Timperlake, E. And Triplett, W. C. 1999. Red Dragon Rising: Communist China's Military Threat to America. Washington, DC: Regnery.

Trckova, D. 2015. "Representations of Ebola and its Victims in Liberal American Newspapers". Topics in Linguistics 16(1) 26-41.

Van Dijk, T. A. 1998. Ideology: A multidisciplinary introduction. New York: Sage Books. Retrieved from http://www.discourses.org/OldBooks/Teun

World Health Organization 2019. Report of the WHO-China Joint Mission on Coronavirus Disease (COVID-19). https://www.who.int/publicationsdetail/report-of-the-who-china-joint-mission-on-coronavirus-disease2019-(covid-19).

\section{Corpus material}

The New York Times [online] available at: http://www.nytimes.com/ 


\section{الجغرافيا السياسية لكوفيد 9 1 : إطار مدوني معرفي رانيا مجدي فوزي لئوني \\ كلية اللغة والإعلام_الأكاديمية البحرية للعلوم والتكنولوي فيا وزي والنقل البحري}

المستخلص

تعني هذه الدر اسة بتحليل ظاهرة تفثي فيروس كورونا، المعروف علميًا باسم COVID-19 من منظور

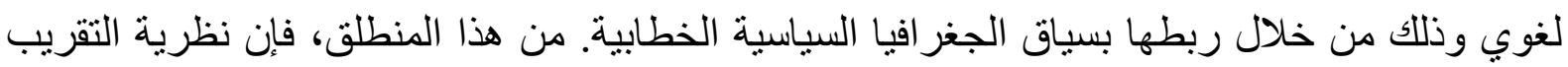
(Cap, 2012, 2017)

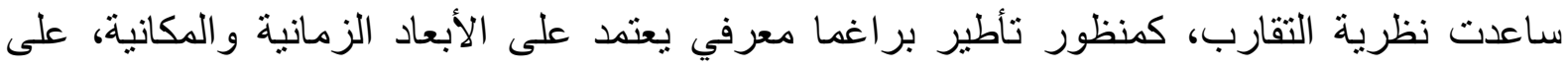

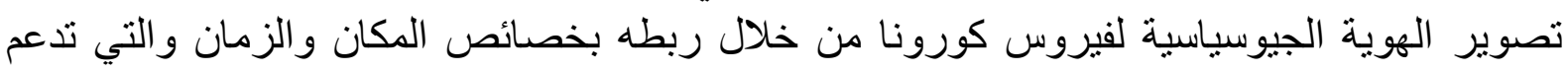
بشكل معرفي الهوية الجيوسياسية للتهديد الصيني وتقربها. كما تستعين الدراسة بنظرية السيناريو المجازي ( Kövecses، Musolff ؛ 2003 ، 2004) ؛

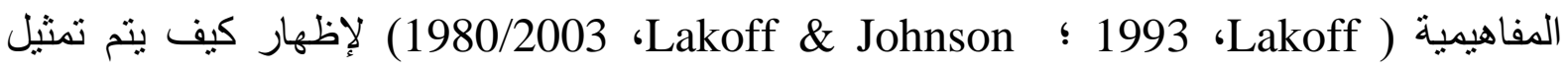
السيناريو الجيوسياسي للتهديد الصيني في نيويورك تايمز. تم وضع الصين أمامنا مكانيًا وزمانيًا باعتبار ها الجاني وراء تفتي فيروس كورونا. تهدف الدراسة إلى إعطاء التوجيه لمجال الجغر افيا السياسية الخطابية من خلال اقتر اح البر اغماتية المعرفية كأداة مناسبة لتحليل بناء الكيانات الجيوسياسية.

الكلمات الافتتاحية: كوفيد 9 (، الجغر افيا السياسية للأمراض، التهديد الصيني، نظرية التقارب، الهوية القائمة على الزمان و المكان 